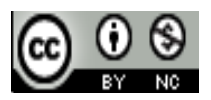

Jurnal Pendidikan Dasar Indonesia is licensed under

A Creative Commons Attribution-Non Commercial 4.0 International License

\title{
STUDY OF PRIMARY SCHOOL TEACHER COMPETENCE IN TANAH BUMBU REGENCY
}

\author{
Dwi Atmono1), Muhammad Rahmattullah ${ }^{2)}$ \\ 1) Economic Education Department, Lambung Mangkurat University, Banjarmasin, Indonesia \\ E-mail:dwiatmono@ymail.com \\ ${ }^{2)}$ Economic Education Department, Lambung Mangkurat University, Banjarmasin, Indonesia \\ E-mail: sarangtiung@gmail.com
}

\begin{abstract}
Teacher competence is central factor that influencing teacher performance to create human resources with certain quality. Teacher competence influenced by many factors, such as educational background and teaching experience for his specific subject. This study aims to: 1) map the competence of primary school teachers in Tanah Bumbu Regency, and 2) analyze the effect of educational background and teaching experience to teacher competence. This study used quantitative approach. Population of this research is all primary school teachers in Tanah Bumbu regency which already followed Online Test of Teacher Competence (UKG Online) as many as 1,106 teachers. Samples were taken by using purposive random sampling as much as $20 \%$ of the total population that numbered 160 people. Variables of this study are: 1) Teacher Competence, 2) Educational Background and 3) Teaching Experience. This study used quantitative analysis includes percentage technique and multiple linear regressions. The results showed: 1) Primary school teacher competence in Tanah Bumbu Regency is above the national average score of 53.05, but still below the Minimum Competence Standards (SKM) of 55. The average score of pedagogic competence is 48.15 and professional competence is 55.91. 2) There is a significant simultaneous effect of educational background and teaching experience to teacher performance. Partially, only teacher experience variable that that significantly influence the teacher competence.
\end{abstract}

Keywords: Teacher Competence, Educational Background, Teaching Experience

\section{INTRODUCTION}

Teacher competence is the main factor in increasing the quality of education especially related with learning quality. Teacher must be a professional educator with complete competence as learning agent. A professional teacher has specific standard of competence includes pedagogy, personality, professional and social competence. Danim (2002) identified the disability of teacher to show their qualified work perfomance is a sign of education crisis in Indonesia. The quality of Indonesian teachers still not so strong. It shown by the result of teacher competence test, that still a lot of teachers didnt qualified the competence test and didnt certified yet. Many teachers didnt understand the substance of knowledge and the ability to implement the right pattern to teach students. From teacher certification program that held by government to create professional teacher, the average score of competence that had been achieved by Indonesia teacher was still under 50 (Gultom, 2013).

To increase the standard of teacher quality, Education Ministry of Indonesia submits three methods of teacher development include competence test, performance assessment, and sustainable training program with a big hope to increase the quality of teacher at many level and subject. The competence test mentioned, known as Teacher Competence Test (UKG). Particullary, the purpose of Teacher Competence Test (UKG) as mentioned in the guide are: 1) the mapping of teacher competence mastering (pedagogic and professional) as basic consideration of the implementation of teachers' cocaching and development program, in the form of suistainable professional development program, 2) as entry point of teacher performance assesment and the control of teacher performance assesment process. (Kemdikbud, 2015). The result of 2015 test indicates unsatisfied result. Cited from www.kemdikbud.go.id (2016), only seven provinces get the best result. Although South Kalimantan Province generally achieved the average score around 53,14, but in Tanah Bumbu Regency still under that average score. Previous studies indicate the real problems that related with the low score of teacher competence in Tanah Bumbu Regency. The result of study by Suratno (2013) shown one of the barrier factor to increase the quality of education at primary level is the teacher factor with the biggest problem on their competence, including from input aspect, educational 
background, preofessional competence, and assesment competence. The latest study by Rahmattullah, et.al (2015) indicates the negatif effect from the low score of teacher competence related with the achievement of National Educational Standards (SNP) at primary level. Teachers had been indicated didnt have fully efforts to facilitate student to reach the maximum learning acquisition. School also didnt facilitate student activities maximally in term of using local potential as learning resources. The learning outcomes in forms of student's masterpiece was still less in term of quantity and quality. The most urgent impact of this problem is the low achievement of student ability and performance, specifically when it standardized by national test result score.

In the framework of policy making about the increasing of teahcer competence at Tanah Bumbu Regency, the mapping of teacher competence is an urgent step as the beginning. This study aimed to: 1) map the competence of primary school teachers in Tanah Bumbu Regency, and 2) analyze the effect of educational background and teaching experience to teacher competence.

Brokejek and Stone (1995) as cited by Jamal (2011) explained that teacher competence is qualitative basic figure about basic behavior of a meaningful teacher. To identify the quality of a teacher, Nurhala and Radito (1986) in Kunandar (2010) argued that teacher must have few competences, include: 1) having knowledge about study and human behaviour, 2) having the right character for themselves, school, colleagues, and their focus subject, 3) mastering their subject content of teaching, and 4) mastering the teaching skill. Johnson (1974) in Sanjaya (2008) said that competence is rational beahivour to reach the specific purpose according to specific condition. According to the 14th Constitution of 2005 about Teahcers and Lecturers, mentioned that "competence is a set of knowledge, skills, and attitude that must be owned, understanding, and mastered by teachers or lecturers in carrying out their professional job. The substance of competence according to Moqvist (2003): "competency has been defined in the light of actual circumstances relating to the individual and work.

Educational background can be a criterion for a professional teacher because this factor has big impact to the level of teachers' pedagogical competence. Danim (2002) explained that: "a teacher can be called as professional based on two perspectives; the first is educational background, and second one is the mastery of teaching material, managing the learning process, managing the student, guidance tasks, etc". Barizi (2009) argued that educational background and teaching experience are two aspects that can influence the professionalism of a teacher in educational aspect.The same idea mentioned by Purwanto (2003), "the more someone experience something, his knowledge and skill about that thing also increase, and he will be more mastering, and with that experience someone can try to get the best result".

Marwanto (2009) explained that educational background and work experience have high impact to teacher performance. Prananto (2008) conclude that educational background, teaching experience, and work ethos took effect on teacher competenc. Saripudin (2014) adding the teacher's attitude about their profession also influence the profesional competence of a teacher. Sahertian (2000) in Wibowo (2009) mentioned few factors that have influence on teacher's pedagogic competence include the knowledge, the skill, and the attitude. Pudyastuti (2010) resumed that there's connection between educational background, teaching experience, and learning process with student achievement. Kartini (2011) revealed eight factors that influence the teacher's professional competence, also including educational background. Sangadji (2013) explained two factors that affected to pedagogical competence of teacher in term of doing their job as curriculum developer, including educational background and their teaching experiences.

\section{METHODS}

This study used quantitative approach. Population of this research is all primary school teachers in Tanah Bumbu regency which already followed Online Test of Teacher Competence (UKG Online) as many as 1,106 teachers. Samples were taken by using purposive random sampling as much as $20 \%$ of the total population that numbered 160 people. Variables of this study are: 1) Teacher Competence, 2) Educational Background and 3) Teaching Experience. This study used quantitative analysis includes percentage technique and multiple linear regressions.

\section{RESULT AND DISCUSSION}

A. The Overview of The Mapping of Primary School Teachers in Tanah Bumbu Regency based on The Online Test of Teacher Competence (UKG) 2015

Based on the field data, the average score of Teacher Competence Test for primary school teachers of Tanah Bumbu Regency is 53,58. This score shows that the competence of primary school teachers in Tanah Bumbu Regency is above the national average of 53.05, but still below the Standard of Minimum Competence (SKM) of 55. Based on average score of pedagogical competence (48.15), the competence of primary school teachers is still below the Standard of Minimum Competence. Based on average score of professional competence (55.91), the competence of primary school teachers is above the Standard of Minimum Competence. The detail overview can be seen in Figure 4.1 below: 


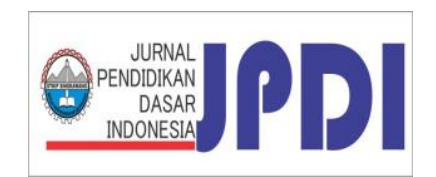

Jurnal Pendidikan Dasar Indonesia

Volum 2 Nomor 1 bulan Maret 2017. Page 5 - 8

p-ISSN: 2477-5940 e-ISSN: 2477-8435

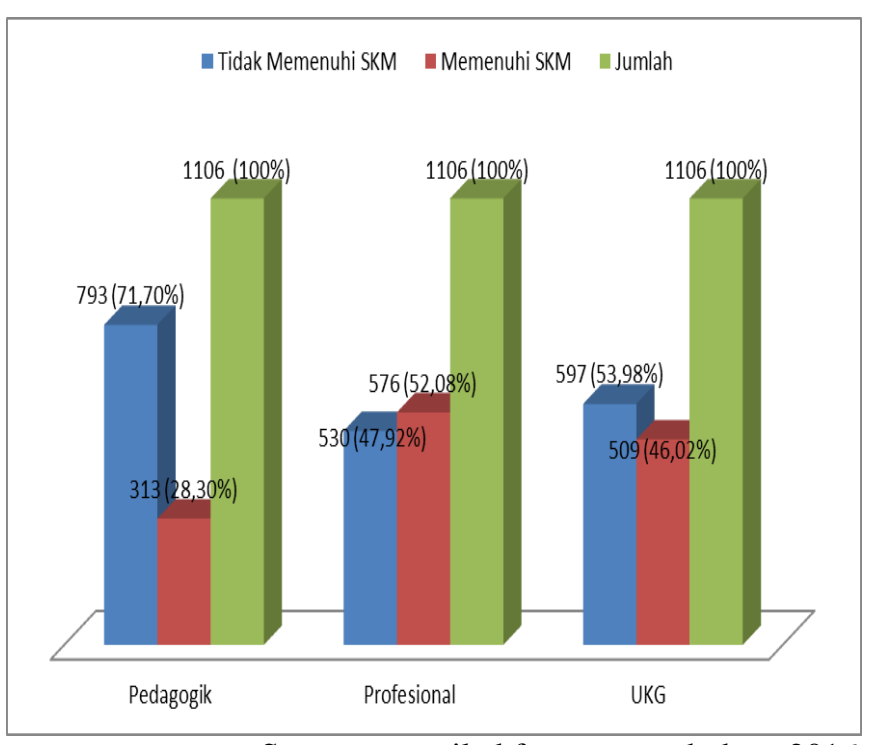

Source: compiled from research data, 2016 Fig. 1 the Results of The Online Test of Teacher Competence (UKG) 2015 For Primary School Teachers in Tanah Bumbu Regency

Primary school teachers in Tanah Bumbu Regency had a variety of their background educational levels. Distribution of educational level that appears in this study are: a) Under the S1 / DIV as much as $14.83 \%$, b) equivalent S1 / DIV as much as $81.74 \%$, and 3 ) the equivalent $\mathrm{S} 2$ as much as $3.44 \%$. This data indicate that most amounts of the teachers who followed the competence test are from "equivalent to S1 / DIV" group.

Primary school teachers in Tanah Bumbu Regency had a variety of teaching experience. The time range of their teaching experience varies from 0-37 years. In this study, the teaching experience is grouped into three categories: a) 0-10 years as many as $45.12 \%$; b) $>10-20$ years as much as $12.57 \%$; and c) above 20 years as much as $42.31 \%$. This data indicate that most of the teachers who attended the competence test are mostly new teachers (into 10 years and under group).

\section{B. The Effect of Educational Background and Teaching Experience to Teacher Competence}

The test results on the influence of Educational Background and Teaching Experience on the Teacher Competence can be seen in Table 1 below:

TABLE 1

SimultaneOUs Test Results

\begin{tabular}{cccc}
\hline Point & F Score & Sig & $\begin{array}{c}\text { Adjusted R } \\
\text { Square }\end{array}$ \\
\hline Simultan & 7,456 & 0,003 & 0,518 \\
\hline
\end{tabular}

Source: compiled from The SPSS Result, 2016

Based on Table 1, it can be seen that simultaneously, Educational Background and Teaching Experience had a significant effect on teacher competence. It supported with F score at 7.456 and significance level at 0,003. Simultaneous effect of these two variables amounted to $51.8 \%$.

Partial effect of each independent variable on the teacher competence can be seen in table 2 below:

TABLE 2

PARTIAL TEST RESUlts

\begin{tabular}{lcc}
\hline \multicolumn{1}{c}{ Variables } & t Score & Sig \\
\hline Educational Background (x1) & 3,655 & 0,002 \\
Taching Experience (x2) & 2.117 & 0,051 \\
\hline
\end{tabular}

Source: compiled from The SPSS Result, 2016

Based on Table 2, it can be seen that only "Educational Background" variable that has significant effect on teacher competence. This finding is supported by the results of descriptive analysis on a previous discussion about the relation of teaching experience and teacher competence. The results also support the preliminary study by Kartini (2011), Sangaji (2013) and Sahertian (2000) in Wibowo (2009) on the effect of educational level on teacher competence.

\section{CONCLUSION}

The conclusions of this study are: 1) Primary school teacher competence in Tanah Bumbu Regency is above the national average score of 53.05, but still below the Minimum Competence Standards (SKM) of 55. The average score of pedagogic competence is 48.15 and professional competence is 55.91.2) There is a significant simultaneous effect of educational background and teaching experience to teacher performance. Partially, only teacher experience variable that that significantly influence the teacher competence.

Recommendations from this study include:

1. The Government of Tanah Bumbu Regency should facilitate the enhancement programs of teacher competence through optimizing the development of continuous profession as the follow-up of the Teacher Competence Test Program. Some forms of real action that can be done include: a) Strengthening The MGMP in order to improve pedagogic and professional competence through the facilitation of supporting activities such as the implementation of Lesson Study and the development coaching model based on MGMPs in form of offline and online models. The reinforcement should be implemented, especially in the designing aspect of learning, various techniques of effective learning, and on assessment competence for teachers; and b) facilitating the training of teachers' writing competence with facilitation from universities, especially to publish all papers through relevant journal in universities or publish teachers' journal at Tanah Bumbu Regency.

2. The local government through the education department should arrange a database related with the development of continuous profession program based on Teacher Competence Test or National Exam Results, to be the reference in determining the form of training and 
education that will be provided. Target training should be focused on teachers with low competence (based on Teacher Competence Test) and consider few supporting factors such as the length of teaching period and the background of their education.

\section{REFERENCES}

Gultom, S. Kualitas Guru di Indonesia Masih Rendah. Retrieved $4 \quad 4, \quad 2014$, from SekolahDasar.Net: http://www.sekolahdasar.net/2013/09/kualitas-guru-di-indonesiamasih-rendah.html. 2013.

Kemdikbud. Pedoman Uji Kompetensi Guru. Jakarta: Badan PSDMPK dan PMP. 2015

Anonim, 7 Provinsi Raih Nilai Terbaik Uji Kompetensi Guru 2015. Diunduh dari http://www.kemdikbud.go.id/main/blog/2016/01/7 provinsi-raih-nilai-terbaik-uji-kompetensi-guru-2015. 2016.

Suratno, dkk. Pemetaan Ujian Nasional Sd/Mi Dan Smp/Mts Serta Pemetaan Potensi Guru Di Kabupaten Tanah Bumbu. Bappeda

Kabupaten Tanah Bumbu. Laporan Penelitian Badan Perencanaan dan Pembangunan Daerah Kabupaten Tanah Bumbu. 2013.

Rahmattullah, Muhammad, dkk. Kajian Pencapaian Standar Nasional Pendidikan (SNP) Pada Jenjang Pendidikan Dasar Di Kabupaten Tanah Bumbu. Laporan Penelitian Kerjasama Jarlit dan Bappeda Kabupaten Tanah Bumbu Tahun 2015. 2015

Jamal M. Asmani. Tips Sukses PLPG (Pendidikan dan Latihan Profesi Guru). Jogjakarta: DIVA Perss. 2011.

Kunandar, Guru Profesional Implementasi Kurikulum Timgkat Satuan Pendidikan (KTSP) dan Sukses dalam Sertifikasi. Jakarta: PT RajaGrafindo Persada. 2010.

Sanjaya, Wina. Kurikulum dan Pembelajaran Teori dan Praktik Pengembangan KTSP. Jakarta: Kencana Prenada Media Grup. 2008.

Moqvist, L. The Competency Dimension of Leadership: Findings from a .Centre for Studies of Humans, Technology and Organisation, 2003.

Danim, Sudarwan. Inovasi Pendidikan Dalam Upaya Peningkatan Profesionalisme Tenaga Kependidikan. Bandung : Pustaka Setia. 2002.

Barizi, Ahmad. Menjadi Guru Unggul. Yogyakarta : Ar Ruzzmedia. 2009.

Purwanto, Ngalim. Psikologi Pendidikan. Bandung : Remaja Rosdakarya. 2003

Marwanto, Arif. Faktor-faktor yang Mempengaruhi Keberhasilan Kinerja Guru SMK Kabupaten Sleman. Tesis tidak diterbitkan. UNY-PPs. 2009.

Prananto, Iwan. Pengaruh Latar Belakang Pendidikan, Pengalaman Mengajar dan Etos Kerja Terhadap Kompetensi Mengajar Guru Ekonomi SMA Negeri di Kab. Bantul. Skripsi tidak diterbitkan. UNY-FISE 2008.

Saripudin, Faktor-faktor Yang Mempengaruhi Kompetensi Professional Guru Bidang Kompetensi Keahlian Teknik Instalasi Tenaga Listrik di SMK. Jurnal INVOTEC Volume X No 1 Februari 2014 Hal 67-88. 2014.

Wibowo, Da'i. Pengaruh Supervisi Kepala Sekolah dan Kompetensi Pedagogik Guru Terhadap Kinerja Guru SD Negeri Kecamatan Kersana Kabupaten Brebes.Tesis, Program Studi Manajemen Pendidikan,Program Pascasarjana Universitas Negeri Semarang. 2009.

Pudyastuti, Septina Galih. Hubungan Antara Latar Belakang Pendidikan Guru, Pengalaman Mengajar, dan Pembelajaran dengan Prestasi Belajar Siswa SMA Negeri 1 Surakarta. Skripsi tidak diterbitkan. FKIP-UNS. 2010.

Kartini, Titin. Faktor-Faktor Yang Mempengaruhi Kompetensi Professional Guru di SMK Negeri 1 Losarang Kabupaten Indramayu. Tesis. FISIP UI, Jakarta. 2011.

Sangadji, Kapraja. Kompetensi Pedagogik Guru Pascapendidikan Dan Latihan Profesi Guru (PLPG) Dalam Melaksanakan Tugas Sebagai Pengembang Kurikulum Studi Pada Madrasah Tsanawiyah Negeri 1 Ambon. Jurnal Fikratuna, Vol. 5, Nomor 2, Juli-Desember 2013: 237 244. 2013. 